\title{
The Clinical Proteomics editorial team would like to announce a change in the volume listings for the journal
}

Clinical Proteomics

c/o BioMed Central, 236 Gray's Inn Road, London, WC1X 8HB, UK

\section{Publisher's note}

Owing to the technical process involved in transferring the journal to its new publisher, BioMed Central, Volume 7 of Clinical Proteomics will now contain only this publisher's note. Volume 8 will contain all articles published in 2010, and all other articles published throughout 2011.

As an online only journal Clinical Proteomics will, from this point forwards, publish one volume annually, with Volume 9 beginning January 2012.

Any questions can be directed to editorial@clinicalproteomicsjournal.com.

Published: 2 December 2011

doi:10.1186/1559-0275-7-1

Cite this article as: : The Clinical Proteomics editorial team would like to announce a change in the volume

listings for the journal. Clinical Proteomics 2011 7:1.
Submit your next manuscript to BioMed Central and take full advantage of:

- Convenient online submission

- Thorough peer review

- No space constraints or color figure charges

- Immediate publication on acceptance

- Inclusion in PubMed, CAS, Scopus and Google Scholar

- Research which is freely available for redistribution

Submit your manuscript at
www.biomedcentral.com/submit

C Biomed Central 